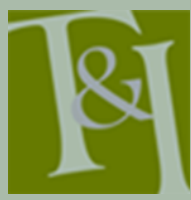

The International Journal for Translation \& Interpreting Research trans-int.org

\title{
The influence of governmental policy on public service interpreting in the Netherlands
}

\author{
Esther de Boe \\ University of Antwerp \\ esther.deboe@uantwerpen.be
}

DOI: 10.12807/ti.107203.2015.a12

\begin{abstract}
In the Netherlands, the government has become involved in public service interpreting by issuing measures shaping the professional conditions for interpreters and by monitoring the quality of their services. Under the Sworn Interpreters and Translators Act (2007) a register was set up for interpreters who meet predefined requirements for "basic interpreter competencies". According to the 2007 Act, institutions in the legal domain as well as in the immigration and police services are obliged to work exclusively with certified interpreters. In this way, the government has contributed to the professionalization of legal interpreting. In recent years however, this development has been reversed in other sectors of public service interpreting (PSI). Some forms of PSI, it would seem, are more equal than others. In public health for example, there are only advisory regulations concerning the use of interpreters, and there is no obligation to work with certified interpreters. Although the government was initially involved in the administration and financing of interpreting agencies in all the fields of PSI, over the years it has gradually transferred this responsibility to the users of these services. In 2012, the government stopped most of its funding of healthcare interpreting. In spite of the presence of several indicators of professionalization of interpreters in the Netherlands, such as certification, a code of ethics, compensation and a system of continuing education for interpreters, their effectiveness is limited because they concern only interpreters working in the legal domain or in immigration and police services. The level of professionalization in PSI as a whole could be increased if the government were to implement its theoretical stance that both legal and healthcare interpreting are matters of public interest enshrined in the Dutch law, and if other fields of PSI besides legal interpreting were included in the existing framework for certification, training and continuing education.
\end{abstract}

Keywords: public service interpreting, legal interpreting, healthcare interpreting, professionalization, certification

\section{Introduction}

Like many other countries in Western Europe, the Netherlands has been a recipient country of an increasing number of immigrants since the 1970s, rendering interpreting in the public services necessary. The Dutch legal framework for interpreting makes no distinction between the different areas of interpreting within public service institutions. Although there are specialized courses for legal interpreters offered by professional organizations, the Dutch institutions that provide interpreter training make no distinction between the different fields and offer general interpreter training courses at bachelor level. In keeping with this situation, the term "public service interpreting" will be used in this paper to refer to all kinds of interpreting in the public sector, including legal interpreting, as defined by Baraldi and Gavioli (2012): 
Community or public service interpreting refers to rather well-established interpreting services in hospitals, courts, immigration offices and other public institutions and is the label that has been given to these services in the Anglophone and Northern European countries (Carr et al., 1997; Corsellis, 2009; Hale, 2007; Roberts et al., 2000). (p. X)

The role of the Dutch government in exercising quality control of translator and interpreter services is ambiguous at best. In 2007, under the Sworn Interpreters and Translators Act (2007), a certification system was implemented in which "certification" was defined as "a voluntary process by which an organization grants recognition to an individual who has met certain predetermined qualification standards" (Stejskal, 2003). The certification system was and still is based on a professional register that manages sworn interpreters and translators; it was an important step towards the professionalization of the interpreting and translating profession. However, the main focus of the Dutch certification system is on public service interpreting in the field of justice, i.e. in cases concerning criminal law, immigration and police interrogation, where the institutions concerned are bound by law to use certified interpreters. Other areas in which public service interpreting is used, such as healthcare, are under no such legal obligation. As a result, the quality of interpreters and translators outside criminal law, immigration and police interrogations is hardly monitored.

Apart from its policy concerning certification, the government's financing policy has also influenced the way public service interpreting has developed in the Netherlands: for instance, it subsidizes TVCN, the Tolk- en Vertaalcentrum Nederland [Dutch Interpreting and Translation Centre], a merger of regional interpreting services, while, in contrast, its suspension of funding of interpreting services in the field of healthcare since 2012 has had serious repercussions for the interpreting profession.

The present paper provides an overview of these shifts in government policy regarding public service interpreting in the Netherlands and investigates how this policy, especially the policy concerning the certification and funding of PSI, has influenced the interpreting profession. I will first briefly discuss the "traits" that characterize the profession of PSI in the Netherlands by means of the sociological trait model of professionalization. After that, I will focus on the most prominent traits by giving an overview of the developments towards certification in the Netherlands, explaining the system and its legal aspects, and by giving a short outline of training and ongoing education. Next, I will look into government policy concerning market regulation, the introduction of fixed hourly fees and the funding of interpreting in the public service domain. Finally, in the conclusion, the most significant features of the government's role in the development of public service interpreting in the Netherlands will be summarized. For the purposes of this paper, only the situation of spoken language interpreters will be considered.

\section{Professional status of the public service interpreter in the Netherlands}

\subsection{Models of professionalization}

Different models have been conceived to assess the professionalization of an occupational group. Early studies of professionalization by Wilensky (1964) and Houle (1980) described the steps and features that indicate the degree of professionalization. These include full-time employment, training, professional associations, political agitation and a formal code of ethics. These studies laid the foundation of 'trait theory' and the 'theory of control' (e.g. Hodson \& Sullivan, 2001; Larson, 1977; Witter-Merithew \& Johnson, 2004). According to trait theory, the degree to which an occupation has achieved its status as a 
profession is determined by a checklist of the attributes it possesses (Pym et al., 2012). Witter-Merithew and Johnson generated the most commonly referenced traits or characteristics of a profession from the existing literature and applied these to determine the degree of professionalization of sign-language interpreters in the US (2004, pp. 5-6).

Table 1. Trait theory characteristics and definitions

\begin{tabular}{|c|l|}
\hline 1. & $\begin{array}{l}\text { Systemic Theory: A set of abstract concepts that describe the focus of } \\
\text { professional service }\end{array}$ \\
\hline 2. & $\begin{array}{l}\text { Authority: Extent of collective influence practitioners have over the policy } \\
\text { making and practice }\end{array}$ \\
\hline 3. & $\begin{array}{l}\text { Credentials: Acquisition of academic and professional recognition to satisfy } \\
\text { established standards }\end{array}$ \\
\hline 4. & Induction: System of transitioning new practitioners into the profession \\
\hline 5. & $\begin{array}{l}\text { Code of Ethics: Public statement regarding service mission and duty owed by } \\
\text { the profession }\end{array}$ \\
\hline 6. & Compensation: Range of salary and benefit options \\
\hline 7. & $\begin{array}{l}\text { Continuing Professional Development: System of on-going availability and } \\
\text { acquisition of contemporary knowledge and skills }\end{array}$ \\
\hline 8. & $\begin{array}{l}\text { Community Sanction: Public recognition of services defined in the practice } \\
\text { standards }\end{array}$ \\
\hline 9. & Culture: Evidence of collective identity via formal and informal networks \\
\hline
\end{tabular}

It is beyond the scope of this paper to investigate in detail the relative presence of all these traits in public service interpreting in the Netherlands. Instead, I will focus on the characteristics that are more or less directly influenced by government policy in the Netherlands, namely certification, quality control and training, which roughly correspond to the traits authority, credentials, code of ethics and continuing professional development mentioned in Table 1.

\section{The government's role in PSI in the Netherlands}

\subsection{Interpreting as a matter of public interest}

Public service interpreting is of interest to the government as it is essential to guarantee that matters of 'public interest', such as legal protection, safety and healthcare function (Felsö et al., 2007, p. 19). For this reason, the Dutch government became involved in the organization and financing of public interpreting services by setting up and subsidizing interpreting agencies since the 1970s (IBO, 2003, p. 9) and by developing a specific legal framework for interpreting. This legal framework specifies the basic requirements that public service interpreters must meet in order to become certified, thereby ensuring a guaranteed minimum quality in public service interpreting. However, as the Sworn Interpreters and Translators Act of 2007 enforces the use of certified interpreters only in the fields of criminal law, immigration and police interrogations, this minimum quality is guaranteed only in these particular fields of PSI. Although in a letter accompanying a final report with recommendations concerning PSI policy by the Ministries of Justice and Immigration Affairs and Integration to the Dutch Lower Chamber in 2004 in which it was claimed the government was ensuring the legal protection of citizens' and patients' access to healthcare as part of its legal duty (Ministeries van Justitie en voor Vreemdelingenzaken en Integratie, 2004, p. 2), its practical policy concerning PSI did not comply with this claim. What is more, other public services besides the legal and medical domain (e.g. education) are not even mentioned in this letter nor are they mentioned in the report in question. The official government working group responsible for formulating measures to improve PSI quality 
recommended regulations for establishing PSI quality standards for the fields of justice, police interrogations, immigration and healthcare (Ministeries van Justitie en voor Vreemdelingenzaken en Integratie, 2004, p. 3). However, in its proposals for concrete measures, it only recommended creating a legal framework for interpreters in legal public services (Ministeries van Justitie en voor Vreemdelingenzaken en Integratie, 2004, p. 6), a recommendation that was put into practice by the implementation of the Sworn Interpreters and Translators Act of 2007.

\subsection{Legal context: a short history}

As mentioned above, the Dutch government has been actively involved in shaping the translation and interpreting profession in the legal context. Since the 19th century, certified translations of certain official or legal documents such as acts, legal proof in court cases or diplomas have been required. According to the former Law on Certified Translators ("Wbv") of 1878, translators could apply for certification "for life" by submitting diplomas or attestations and were subsequently sworn in during a court session, after which the translator received an "act of certification". For interpreters there were no such regulations. If necessary, interpreters were sworn in for individual court sessions (Bureau BTV, n.d.).

From the mid-1970s, a legal arrangement for interpreters was called for by the professional organization, the Dutch Society of Interpreters (NGT, later called NGTV) [the Netherlands Association of Interpreters and Translators], which even developed its own Bill, and by the so-called "Coornhert Liga", an association that campaigned for the reformation of criminal law (Doornbos, 2008). Moreover, several publications within jurisprudence investigated the question as to whether interpreters in criminal law should meet supplementary demands in addition to the basic interpreter profile that was being developed by the government (Duijn \& Reijen, 2001, p. 5).

At the end of the 1980s, the European Court of Human Rights (ECHR) decided that governments are responsible for organizing and maintaining a system of free interpreting services for suspects in criminal cases (Doornbos, 2008; Felsö, 2007, p. 20). The investigation of the consequences of this European jurisprudence was assigned to a "Re-evaluation Criminal Proceedings Commission", also known as "Commissie-Moons", by the Dutch Ministry of Justice. Its report argued strongly in favour of a legal framework with quality requirements for interpreters, in line with the decisions of the ECHR concerning the Kamasinski case, which established that the interpretation provided in criminal proceedings should be of a high enough standard to enable the defendant to have knowledge of the case against him and to defend himself: see Doornbos (2008).

Moreover, several complaints arose about the performances of interpreters in the 1980s and 1990s, when a high influx of asylum seekers led to an increased need for interpreters. As a result, the Immigration and Naturalization Service (IND) responsible for the implementation of asylum policy in the Netherlands often resorted to underqualified interpreters. The Nationale ombudsman ["National ombudsman"] carried out two investigations concerning IND interpreters after complaints were lodged about their performance (Kleij, 2015, p. 4). In 1996, partly as a response to these investigations, the IND published official regulations for interpreters, which included the establishment of a code of conduct as well as a complaints committee. Within the framework of the Sworn Interpreters and Translators Act, the IND complaints committee was followed in 2009 by a new committee, the Sworn Interpreters and Translators Complaints Committee ["Klachtencommissie Wbtv"], which also dealt with complaints concerning interpreters in other organizations that come under the Ministry of Justice (Kleij, 2015, p. 5). 
The actual developments that would lead to a new legal framework for interpreters started in 1998, with the recommendation by the "Official Interpreting and Translation Services Working Group" [Ambtelijke werkgroep tolk- en vertaaldiensten] to formulate general requirements regarding quality, integrity and education and the certification of interpreters and translators in public services on the basis of these requirements (Doornbos, 2008). Accordingly, a "quality trajectory" for legal interpreting was started in 2001, based on the recommendations of the "Legal Interpreters Working Group" [Werkgroep Gerechtstolken]. The objective of this quality trajectory was to arrive at a situation, from 2003, in which the Ministry of Justice would work only with legal interpreters who met a certain quality level and would enforce fixed rates. A preliminary "quality agreement" was to be signed between the government agency responsible for interpreter and translator quality, named the "Interpreters and Translators Quality Bureau" [Kwaliteitsbureau Tolken en Vertalers], and registered interpreters (Duijn \& Reijen, 2001). For this purpose, a temporary "quality register" of interpreters and translators was created. Because the government considered the capacity of the interpreting sector to regulate itself to be insufficient, a special commission consisting of legal interpreting experts and clients, the "Commission for Quality Requirements for Interpreters and Translators in the Legal Domain" (also known as the "Commissie-Jurgens"), was set up in 2003 (Ministeries van Justitie en voor Vreemdelingenzaken en Integratie, 2004, p. 6). The temporary register was superseded by an official register in 2007 within the framework of the new Sworn Interpreters and Translators Act.

2.2.1 Sworn Interpreters and Translators Act: content and organization. The new 2007 Sworn Interpreters and Translators Act (Wbtv) replaced the regulations of 1878 and became operative from 1 January 2009. The purpose of this law is:

[...] safeguarding the quality and integrity of interpreters, for which purpose it provides the following instruments: quality and integrity requirements, a system of continuous education, the oath and a complaints procedure. The law is founded on two segments: on the one hand a quality register for certified translators and interpreters, and on the other, the obligation of institutions in the legal domain to work exclusively with translators and interpreters subscribed to this register (Doornbos, 2008, translation present writer).

The law stipulates that in order to be able to apply for registration, interpreters must meet requirements concerning the following competencies: interpreter attitude and integrity, language proficiency in the source and target languages, knowledge of the culture of the source and target languages, and general interpreter competencies, all of which are part of the general interpreter curriculum at bachelor level in the Netherlands. An interpreter who wants to be entered in the register must provide evidence of having completed a specific diploma in interpreting at bachelor level (a detailed explanation of the various diplomas is provided in section 2.2 .4 below). If an interpreter holds no such diploma, he or she must provide specific proof of experience (of at least 5 years) and continuing education in interpreting (see section 2.2.5) (Bureau btv, 2013).

In 2003, the Dutch Ministry of Justice appointed the Legal Aid Board to implement the new law and created the "Register of Sworn Interpreters and Translators" ("Rbtv"). Within the Legal Aid Board, the Bureau for Sworn Interpreters and Translators ["Bureau voor Beëdigde Tolken en Vertalers"] is responsible for managing the register by:

1. developing policies for the implementation of the Wbtv law and for advising on future developments to further reinforce the quality of interpreting and translation services within the field of justice; 
2. considering complaints that are filed against registered interpreters and translators;

3. appointing institutions and experts that are allowed to organize linguistic and cultural tests;

4. appointing institutions offering continuing education;

5. issuing confirmation of registration for the purposes of the swearingin procedure;

6. issuing interpreter and translator IDs;

7. providing information about the Act's functioning via brochures, a website and newsletters.

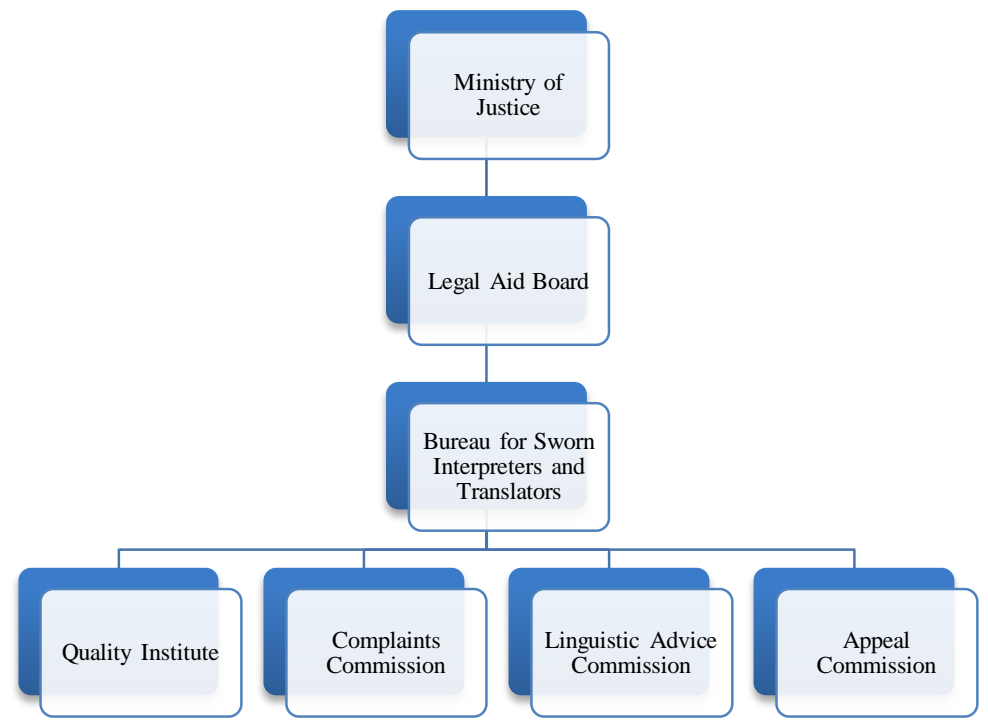

Figure 1. Organizational chart

Article 28, paragraph 1 of the Sworn Interpreters and Translators Act (Wbtv) makes it compulsory for the following government services within criminal law and immigration law to use only certified translators and interpreters:

- the department of administrative law of the Council of State [Raad van State];

- the courts of justice;

- the Prosecution Council [Openbaar Ministerie];

- the Immigration and Naturalization Service [Immigratie- en Naturalisatiedienst];

- the police;

- the Royal Military Police [Koninklijke Marechaussee].

2.2.2 Code of ethics. Within the framework of the Wbtv, a code of ethics was set up in 2009 (Bureau btv, 2009), the content of which is based on a text that was formulated by a large number of national branch organizations of interpreters and translators in Europe (Bureau btv, 2014). In addition to that, the experience of the Dutch Order of Lawyers and their legal expertise with a comparable code of ethics was drawn on (Bureau btv, 2014). The code of ethics for translators and interpreters was further developed by delegates of Dutch branch organizations represented in the Quality Institute, namely three members of the Netherlands Association of Interpreters and Translators (NGTV), three members of the Alliance of Interpreter and Translation Organizations [Alliantie van Tolk- en Vertaalorganisaties], two members from the legal fraternity, two members from the field of training for interpreters and translators, and representatives of the Council for Refugees in the Netherlands 
[VluchtelingenWerk Nederland] (Bureau btv, 2009). The code of conduct prescribes aspects of interpreting concerning "general interpreter attitude" (guarantee of quality and impartiality), "collegiality", "professionalism" (competencies and continuing education), "exercise of professional duties" (contracts and responsibility of complete and efficient communication) and "complaint procedures" (Bureau btv, 2009).

The Immigration and Naturalization Service (IND) developed its own code of conduct for interpreters working for this service [Gedragscode tolken]. This was updated in 2014 (Immigratie- en Naturalisatiedienst, 2014) and focuses on the specific working conditions of interpreters in immigration affairs (Kleij, 2015, p. 8). However, certified interpreters working for the IND are also bound by the general code of conduct as formulated by the Legal Aid Board, in conjunction with the specific IND code of conduct (Bureau Btv, 2009).

2.2.3 Certification procedure. At present, interpreters who wish to be sworn in must submit a request to be included in the Rbtv register together with a recent "certificate of good conduct" (police clearance certificate) and copies of relevant diplomas. The fee for inclusion in the register was 125 euros in April 2015. To be registered, interpreters must meet the conditions on qualifications or work experience stipulated in the 2007 Wbtv law. Relevant diplomas are either a certified copy of a diploma issued by an institution for interpreting training at bachelor level at least, or a certificate testifying that the holder has successfully completed the interpreter test recognized by the Legal Aid Board, or a diploma in "court interpreting in criminal cases" [Gerechtstolken in strafzaken] issued by SIGV, the Association of Court Interpreters and Legal Translators, which provides training for court interpreting and translation. If interpreters cannot meet these conditions, they can still be included in the register if they can provide evidence of competence in the source language as well as the target language at the $\mathrm{C} 1$ level of the Common European Framework of Reference for Languages and evidence of having successfully completed a minimum of 420 hours of education with the purpose of developing interpreter skills and interpreter "attitudes". This education should consist of memory training, text analysis and paraphrasing as well as note-taking techniques. In addition, interpreters have to provide evidence of at least five years' experience as a professional interpreter in the language combination they wish to be certified in. These five years must directly precede the date on which the request for certification is submitted, and of these five years, at least one year of work experience must have been gained after having completed the 420 hours of education (Bureau btv, 2013).

Apart from the official register, an alternative or "shadow" list, the socalled "Uitwijklijst", was created in 2009 for interpreters who cannot provide evidence of their proficiency at $\mathrm{C} 1$ level and of their cultural knowledge of the country or area of either their source or their target language. This may be the case when no independent experts are available for assessing an interpreter's training or knowledge in these languages. After an evaluation of the efficacy of this alternative list in 2011, it was concluded that the list needed to be considered more as a temporary "gateway" for interpreters to enter the official register than had been the case until then. As a result, it was officially decided that the time for which interpreters can be registered on this list should be limited to only three years (instead of five), renewable for another maximum of three years if interpreters meet the conditions required concerning work experience and continuing education. These conditions are similar to those required of interpreters in the official register (see section 2.2.5) (Staatscourant, 2011).

Once the qualifications have been verified, interpreters receive notification that allows them to submit a request to be sworn in (either by oath or by affirmation) at the tribunal of the legal district of their residence. If the request 
is granted, the interpreter will receive an invitation to appear before the judge. During this session, the interpreter must confirm the text of the oath spoken by the judge, after which they receive an "act of certification", a copy of which has to be delivered to the Bureau for Sworn Interpreters and Translators (Bureau btv, 2013). In January 2013, 1,602 interpreters were listed in the register (Rayar, 2013). According to its policy plan, the Bureau for Sworn Interpreters and Translators aims to increase this number to 5,000 by the year 2020 (Bureau btv, 2012).

The public services in the legal field - which are obliged to work with certified interpreters - must give priority to an interpreter in the register and can turn to the alternative register only if their needs cannot be met and on the condition that a written explanation is provided. If no interpreter can be found through the alternative register, an institution can resort to a non-certified interpreter, which again has to be motivated (Staatscourant, 2013). According to information provided by e-mail by the Legal Aid Board, 266 interpreters were registered on the alternative list in November 2013.

2.2.4 Interpreter training. Within the framework of the 2007 Wbtv law, the Bureau for Sworn Interpreters and Translators has set up a national profile of competencies for colleges of higher education at bachelor level in the Netherlands. These competencies concern interpreting techniques, linguistic, cultural, (re)search and technical competencies, and business-oriented competencies (Bureau btv, 2010). In the Netherlands, the two main bachelor courses in interpreting are organized by the ITV Hogeschool [College of Higher Education] in Utrecht and the Vertaalacademie [Translation Academy], part of the Zuyd College of Higher Education in Maastricht. Both offer a three-year joint training programme for translators and interpreters, after which students specialize in their fourth and final year in either interpreting or translating. Maastricht offers English, German, French and Spanish, whereas ITV, in addition to these languages, also trains interpreters in Italian and Russian. ITV organizes the course "General interpreting techniques for advanced learners" [Algemene Tolktechnieken voor gevorderden], which provides the 420 hours of interpreter training required for inclusion on the register in the event that an interpreter has no interpreting diploma at bachelor level, as mentioned in section 2.2.3 above.

Interpreters trained in Flanders, the Dutch-speaking region of Belgium where interpreter training in Dutch at post-graduate Master's level is offered in Antwerp, Brussels, Leuven and Gent, can also apply for certification in the Netherlands.

2.2.5 Continuing education. The registration of interpreters is valid for five years. If they wish to renew their registration after this period of time, they must have completed a minimum of ten assignments and submit evidence of having obtained 80 points through continuing education ["permanente educatie", or "PE"]. One point represents 60 minutes of education. There are different categories of PE; $50 \%$ of the required points must be obtained in a-d, whereas categories $\mathrm{e}-\mathrm{h}$ are optional (Bureau btv, 2013).

The market for continuing education is still developing and consists of commercial training centres that specialize in translating and interpreting. Such training centres include KTV [Kennisnet voor Vertalers en Tolken/"Information Network for Translators and Interpreters"], TolkenSelect, OCPE [Opleidingscentrum Permanente Educatie/"Education Centre for Continuing Education"], Avila Coaching, Het Talenhuis ["The Language House"], EBTV [Educatie voor Beëdigde Tolken en Vertalers/"Education for Sworn Interpreters and Translators"] and a few others. Professional associations such as the Association of Court Interpreters and Legal Translators ("SIGV") also provide professional development courses. 
Table 2. Categories of Continuing Education

\begin{tabular}{|l|l|}
\hline a & Language and culture \\
\hline b & Terminology and phraseology \\
\hline c & Translation and interpreting techniques \\
\hline d & Domain-specific knowledge and background information \\
\hline e & (Technical) translation tools \\
\hline f & IT applications relevant to interpreters and translators \\
\hline g & $\begin{array}{l}\text { Entrepreneurship: administration, accountancy, taxes, acquisition, } \\
\text { etc. }\end{array}$ \\
\hline h & Quality assurance \\
\hline
\end{tabular}

Since 2012, interpreters have been able to apply for a "specialization" - an acknowledgement of "specific skills" ["specifieke vaardigheden"] - in addition to their basic interpreter competencies (Staatscourant, 2012a). The only specialization available in 2015 is "interpreter in criminal cases". In order to apply for this specialization, an interpreter must have successfully passed the course "court interpreting in criminal cases", mentioned in section 2.2.1, and provide evidence of at least 50 hours of relevant professional experience in this field (Staatscourant, 2012b). The Bureau for Sworn Interpreters and Translators aims to develop a total of five different specializations by 2017 (Bureau btv, 2012, p. 16).

Since February 2015, institutions offering continuing education for interpreters can apply for an official acknowledgement through the Bureau for Sworn Interpreters and Translators. To obtain this, they must provide a "quality plan" containing detailed information about their institution's vision and strategy on continuing education in general and the safeguarding of the quality of their courses more specifically (Staatscourant, 2015a). The institutions that have been acknowledged so far are KTV, OCPE and Tolken Select (Bureau btv, 2015). The Legal Aid Board aims by mid-2015 to have developed a digital system that allows interpreters to register their PE points themselves (Raad voor Rechtsbijstand, 2015).

2.2.6 Practical difficulties with the implementation of Wbtv. A few problems with the implementation of the government's quality policy have already been observed in the practice of PSI: Firstly, an objective test of interpreters and translators of languages of limited diffusion in the Netherlands is not available in some languages; secondly, the police and the justice department often give priority to the speedy progress of their investigations rather than to the quality of the interpreting services they use, and thirdly, the obligation to work only with certified interpreters ["afnameplicht"] is not monitored by any institution (Doornbos, 2008). BTV, the bureau responsible for overseeing the register of sworn interpreters and translators, has indicated in its Policy Plan 2012-2015 that the verification of the observance of the afnameplicht will be watched more closely by providing more information about this obligation and also about the possible sanctions for failing to do so. The aim is to implement these sanctions "on the basis of research and jurisprudence" (Wbtv, 2012, p. 18), but what this means exactly is not specified. No concrete measures for imposing sanctions are mentioned in the policy plan. According to the btv Bureau, the use of certified interpreters and hence the afnameplicht will be "reinforced" once the possibility of specialization for interpreters in the register has been fully developed, which should also facilitate the search for qualified interpreters within a specific domain (Wbtv, 2012, p. 18).

Another problem mentioned by Doornbos (2008) concerns the integrity of interpreters who are not Dutch citizens and/or who have received their training outside the Netherlands. Corrupt regimes in foreign countries may issue 
documents such as diplomas and police clearance certificates, the authenticity of which may be difficult for the Dutch government to establish.

On the side of the interpreters, complaints are voiced about the costs of the obligatory continuing education. In the first period after the system of continuing education was introduced (2009-2014), the average fee for one hour of training was around 50 euros including travel costs, which amounts to 5,000 to 6,000 euros in all for 100 hours of PE points (the compulsory 80 points plus 20 points of specialization). This is an investment that interpreters have to be willing to make every five years (Rayar, 2013).

\subsection{Regulations in healthcare interpreting}

The government became involved not only in determining regulations in the legal domain; it also took an interest in the field of healthcare interpreting, albeit to a much lesser degree, by ordering the creation of "field norms" for the use of interpreters in healthcare institutions in 2006. These norms were developed by the government agency for healthcare inspection, the Health Care Inspectorate ["IGZ"], in a working group consisting of members of several social organizations dealing with immigration and physical and mental healthcare.

The call for field norms resulted from several incidents related to communication problems in healthcare. One such complaint involved a Moroccan woman who had undergone an abortion without her consent while being accompanied by a family member who interpreted for her, whereas a professional interpreter should have been provided by the healthcare institution in question. As a result of this incident, the State Secretary of Public Health, Well-being and Sports ("VWS") approached all institutions that were licensed to perform abortions according to the Abortion Act ("Waz") in 2003 with a written request to make as much use as possible of the free services of qualified interpreters supplied by TVCN (in accordance with the qualification norms applied by TVCN) (IGZ, 2006a, p. 3). According to the Health Care Inspectorate, healthcare laws include several requirements concerning, among other things, accuracy, efficiency and a patient-oriented approach in healthcare, which can be met only when patients/clients and healthcare providers are able to communicate with one another. The Medical Treatment Agreement Act ("Wgbo, 1994), for instance, explicitly states that communication must take place "in a language that is understandable for the patient", whereas in the Clients' Right to Complaints Act ("Wkcz", 1995), the Quality of Healthcare Institutions Act ("Kwz", 1996), the Professions in Individual Healthcare Act ("Wbig", 1993) and the Abortion Act ("Waz", 1984), this norm is implicitly present in the sense that their requirements cannot be met if communication does not take place in a language that is understandable to the patient (IGZ, 2006a, p. 4).

Article 5 of the last-mentioned act (Waz) stipulates supplementary demands concerning accuracy in care provision and decision-making; the patient must be provided with motivated information concerning other possible options beside abortion and the care provider must ascertain that the patient's decision is based on careful consideration of all the options. In addition, after the abortion, the patient must be supplied with information about how to prevent an unwanted pregnancy, all of which requires communication "in a language that is understandable for the patient" (IGZ, 2006a: 7). However, the right to an interpreter is not formulated explicitly in any of the laws mentioned above (Felsö et al., 2007, p. 21).

In addition to studying the legal framework, the Health Care Inspectorate investigated the state of play concerning the use of interpreters in healthcare at the time (2006). It observed a lack of clear directives on the side of care providers, which was associated (among other things) with a lack of attention to interpreting issues at medical schools (IGZ, 2006a, p. 9). 
The field norms the Inspectorate set up recommended that medical aid providers use professional interpreters "in case one is not able to communicate in a language that is understandable for the patient" and strongly discouraged the use of informal interpreters such as friends or family members. Further, it promoted remote interpreting by telephone

"unless one needs to explain something by using images, working with several people at the same time, when several foreign languages are used or when one has to conduct a conversation that is difficult for the client" (IGZ, 2006b).

Although these field norms referred to several laws concerning patients' right to qualitative healthcare, as mentioned earlier, they had no binding character. Moreover, when it became difficult to apply the field norms as a result of the withdrawal of funding for healthcare interpreting in 2012, new guidelines were created. These so-called "quality norms for the use of interpreters for non-native citizens in healthcare" continue to acknowledge that there is a legal foundation for the use of interpreters in healthcare but no longer insist on the use of professional interpreters. Instead, they recommend that care providers follow a step-by-step plan in case of communication problems with patients in order to ascertain whether the use of an interpreter is necessary in the first place and, secondly, whether they should be a professional or an informal interpreter (KNMG, 2014, p. 9). The guidelines do state that serious costs can be incurred later as a result of miscommunication in healthcare situations, referring to research providing evidence of this by Jacobs et al. (2004, 2005), Ku and Flores (2005) and Muela Ribera et al. (2008) (KNMG, 2014 , p. 6). However, just as with the field norms, the new quality norms are merely intended to be advisory.

Finally, and ironically, even though the main intermediary for interpreter services in healthcare, the TVCN, Tolk- en Vertaalcentrum Nederland [Dutch Interpreting and Translation Centre] does have an internal code of ethics and a system for complaint registration, it also employs non-certified interpreters.

\section{Funding and market regulation}

\subsection{Funding}

Following the creation of a legal framework to guarantee a minimum quality of interpreters, the government set out to organize and finance public service interpreting as early as 1977 . At the time, six regional interpreting centres were set up with the financial help of the former Ministry of Health and Environmental Health and the Ministry of Culture, Recreation and Social Work. Clients of these centres paid a fee for using interpreter services. By 1983/1984, clients that were entitled to subsidies could use the services free of charge. The former Ministry of Health, Well-being and Sports handed over the responsibility for the centres to the Ministry of Justice in 1996, the motivation being that "the interpreting centres mostly implement tasks in domains that concern the Ministry of Justice" (Tweede Kamer der Staten-Generaal, 1996, translation by the present author).

In 2000, the six centres merged into one central agency, TVCN, Tolk- en Vertaalcentrum Nederland [Netherlands Interpreting and Translation Centre], which until its privatization in 2006 administered the allocation of interpreters both within and outside the public domain (IBO, 2003, pp. 9, 24). As the TVCN was fully subsidized, it offered free interpreting services to clients in the public sector, with the exception of the courts of justice, the police and the IND (Immigration and Naturalisation Service), which had their own budgets and arranged the employment of interpreters themselves (Felsö et al., 2007: 25). The IND, for example, worked with a pool of interpreters and had internal rules 
covering their employment and payment (Felsö et al., 2007, p. 26). The same applied to the courts of justice, which also had their own cadre of interpreters and accounted for $40 \%$ of the market for PSI in 2007 (Felsö et al., 2007, p. 26).

These parallel systems made the organization of the market for PSI services anything but transparent. In addition, owing to the lack of an incentive for TVCN to deal efficiently with the budget provided by the government, as a larger number of services implied greater subsidies, the government was forced to foot the bill and was confronted with high costs, also because no efficient system was in place for the cancellation of previously ordered services (Felsö et al., 2007, pp. 25-26).

Since 2003, the government has sought to gradually reduce its involvement in administering the allocation of interpreters and their funding in the public sector by implementing the policy recommended in the report on the Interdepartmental Policy Review on Interpreters and Translators ("IBO") in 2003. This report proposed a number of measures to improve the deployment of interpreters in the public sector. It advised the government, for instance, to abandon its policy of financing all PSI and instead recommended that clients of public interpreting services (except for interpreting services in the field of criminal law and immigration) cover the expenses themselves.

In 2005, the effects of the measures planned in the report of the Interdepartmental Policy Review concerning the introduction of market forces in interpreting services in terms of quality control, availability and costs were assessed in a study by the Research and Documentation Centre, a government agency that investigates issues concerning security, criminal, civil and administrative justice and migration issues. The assessment report (Felsö et al., 2007) provided an extensive economic analysis of the interpreting market in the public domain and concluded that the biggest problem in the PSI market was a lack of transparency in matters relating to the quality of interpreter services, a problem that was partly tackled by the government (acting in the role of a client) by collectively setting minimum criteria through the introduction of the quality register (Felsö et al., 2007, p. vii).

In 2009, a cost-benefit analysis of interpreting services was carried out following a sudden increase $(25-50 \%)$ in the use of interpreting services in healthcare, especially in youth welfare, university hospitals, services for the disabled and mental healthcare, and also by general practitioners (van Osenbruggen, 2009, p. 1). The reason for this rise was an increase in internal professionalization within these institutions with respect to, among other things, the use of interpreters and the increased information that was made available about the use of interpreters (Tromp, 2008) - for example, by the publication of the field norms in 2006.

The cost-benefit report concluded that the directly quantifiable benefits of the use of professional interpreters were lower than the costs, although it mentioned that if the costs of patients being wrongly or unnecessarily referred to (more expensive) specialized care had been taken into account, the benefit of interpreters would have been substantially higher (Osenbruggen, 2009, p. 39). Savings recommended by the report mainly concern cutting no-show rates and a reduction in the costs of travel and waiting times for interpreters.

The inefficient use of interpreters in healthcare and the direct costs related to this eventually made the Ministry of Public Health, Welfare and Sport decide to all but suspend the funding of interpreter services in healthcare in 2012. This decision also reflected gradual changes in the political climate. The use of interpreters had come to be seen as a "wrong signal" to citizens of foreign descent, obstructing integration and discouraging them from mastering the Dutch language (Ministeries van Justitie en voor Vreemdelingenzaken en Integratie, 2004, p. 3) (see also section 3.2). The only interpreting services within healthcare that continued to be subsidized were those called upon by "the most fragile groups", namely, foreign victims of human trafficking (financed 
by the Ministries of Justice, Foreign Affairs and Public Health, Welfare and Sport, and CoMensha, an organization that coordinates help to victims of human trafficking) and women staying in shelters for victims of domestic violence (Ministerie van Volksgezondheid, Welzijn en Sport, 2013, p. 3).

\subsection{Implications of funding decisions}

As a direct result of the withdrawal of funding of interpreter services outside the field of justice, the use of interpreter services in the field of healthcare has dropped dramatically, especially among general practitioners and in mental healthcare where a decline of up to $75 \%$ has been observed (Ministerie van Volksgezondheid, Welzijn en Sport, 2013: 4). In contrast to interpreting services in the field of criminal law and immigration, the government policy on financing interpreting services in healthcare institutions is explicitly guided by the principle of the patient's or client's own responsibility to speak the national language of the country, namely, Dutch. The emphasis is on the patient's duty to inform medical personnel of his or her medical condition in a clear and complete way, as laid down in the 1994 Law on Medical Treatment Agreement, and not on the care provider's duty to guarantee communication in a language that is understandable for the patient, laid down in the same law.

According to the Royal Dutch Society for the Advancement of Medicine (KNMG), one of the largest health organizations in the Netherlands, which looks after the interests of doctors and medical students, the suspension of funding puts doctors at risk of violating the law. In a publication of its official position, the KNMG points out that according to the professional code for healthcare providers, elaborated in the Wgbo law mentioned above, doctors must provide high-quality care (Wgbo article 7: 453 Dutch Civil Code). Furthermore, doctors are under an obligation to inform patients in an understandable manner (Wgbo, art. 7:448 Dutch Civil Code). During the development of the Wgbo, the government was questioned by the KNMG about this communication issue. The government's reply was that if a patient does not speak or understand Dutch, doctors could apply for free interpreter services offered by interpreting centres for minorities, financed by the government. During the evaluation of the Wgbo in 2000 and on several other occasions, it was recommended that medical staff use interpreter services or informal interpreters only if the patient agreed. The KNMG argues, however, that the suspension of funding for professional medical interpreters could lead to doctors no longer being able to guarantee respect of the "field norms" (see section 2.4) and patients' rights to responsible care and informed consent (KNMG, 2011; Bot, 2013, p. 75). As indicated in section 2.4, apart from the Wgbo, patients' rights and care providers' obligations are laid down in two further laws: the Clients' Right to Complaints Act [Wet Klachtrecht Cliënten Zorgsector, "Wkzc"] and the Law on Quality of Health Care Institutions [Kwaliteitswet zorginstellingen] (Bot, 2013, pp. 45-46).

In 2013, Edith Schippers, the minister responsible for public health, sent an official letter to the Dutch Lower Chamber in which she drew up an inventory of the situation on the ground with respect to healthcare interpreting. In this publication, the minister states that there are no data proving that the quality of healthcare has been adversely affected since the withdrawal of funding for interpreter services and that there is no quantitative evidence for the argument that a suspension of the funding of interpreting services has led to higher costs in healthcare as a result of the predicted increase in general practitioners referring patients to specialist care. According to the publication, a shift from professional to informal interpreters has taken place. In addition to that, the minister states that the use of medical personnel speaking languages other than Dutch has increased, rendering professional interpreters partly redundant. She also mentions that hospitals are now paying the costs of interpreting services themselves (Ministerie van Volksgezondheid, Welzijn en Sport, 2013, p. 2). 
This was confirmed in research by Medisch Contact /Artsennet ["Medical Contact/Doctors' Network"], an information website for and by medical professionals that also mentions a shift from face-to-face interpreting to remote interpreting by telephone, another way of saving on interpreting costs (Visser, 2013). A Dutch online communication platform for medical policy-makers comes to the same conclusion: Nowadays, hospitals finance interpreting services themselves (Skipr, 2012). The minister does emphasize the importance of good communication in healthcare and points out that in so far as interpreting is concerned, an exception is made for weaker patients, especially victims of human trafficking and asylum seekers, who are unlikely to be proficient in Dutch (Ministerie van Volksgezondheid, Welzijn en Sport, 2013, p. 4). Interpreter services for these specific groups are funded through the NGO CoMensha, which registers victims of human trafficking and coordinates care in this field. Interpreters' objections to the government policy were centralized through the initiative "Wij zijn sprakeloos" [We are speechless] in 2013 by Mikado, an intercultural care organization.

\subsection{Market regulation}

3.3.1 Public tendering. The 2003 IBO report mentioned in section 2.3 also advised against the government acting as an agent between clients and interpreters. This resulted in a public tender being issued for interpreter agencies to act as an intermediary between the client (i.e. the government) and the interpreter. The tender was won by Manpower Solutions, the parent company of TVCN, and their contract started officially in 2006 (Felsö et al., 2007). From 2006, it also became government policy to bundle larger numbers of interpreting assignments in the legal field and put them out to tender as well. In 2009 , the Dutch government further reduced its involvement in public service interpreting by calling for tenders for an intermediary agency to provide interpreters for cases of legal assistance. This tender was won by the Concorde Group interpreting and translation agency. Between 2006 and 2009, the Ministry of Justice spent some 75.6 million euros on tendered interpreting services (Baarsma \& Prins, 2013, p. 3). Meanwhile, the total amount spent on public tenders for interpreting services has risen to 150 million euros a year according to NGTV, the Netherlands Association of Interpreters and Translators (2015). On the supply side, this has had an impact on the management of agencies, which need to be of a considerable size to handle the large contracts. Smaller agencies such as TolkenSelect and SIGV-Coöperatie can hardly compete with the two giant agencies TVCN and Concorde Group, and the independence of freelance interpreters, who have come to depend much more on agencies for their assignments, is at stake. On the demand side, this situation has provided the government with disproportionate power to set low rates of payment (Baarsma \& Prins, 2013, p. 4).

3.3.2 Tariffs. As far as price regulation is concerned, it is obvious that the government controls the market $(70 \%$ of the total turnover of the entire market of interpreting services in 2007) and is therefore able collectively to negotiate lower rates, which private clients who cannot coordinate and centralize their demand cannot do (Felsö et al., 2007, p. viii). In fact, the Dutch government established fixed rates for interpreters in criminal cases as early as 1963. Between that year and 1981, the rates were indexed almost every year, but they have not been indexed again since (Baarsma \& Prins, 2013, p. 4). The 2003 decision on tariffs in criminal cases [Besluit inzake Tarieven in Strafzaken] confirmed the fixed hourly rate for interpreters in this domain as 43.89 euros for all languages and a call-out fee of 20.23 euros. For interpreters who started working for the institutions in the Dutch legal environment before 2001 different tariffs apply, and a distinction is made between European languages 
(46.29 euros/hour), common non-European languages (48.60 euros/hour) and rare, non-European languages (54.00 euros/hour) (Staatsblad, 2003).

In 2005, steps were taken to liberalize the PSI market with the agreement that clients from the Dutch Interpreting and Translation Centre (TVCN) would pay fixed rates for interpreting services, but TVCN was allowed to apply differentiated rates for interpreters. As a result, it could decide for itself the amount of commission to be charged on the interpreting services and the rates paid to the interpreter (Felsö et al., 2007, p. x). According to the 2003 IBO report, the deregulation of rates could create openings for differentiation based on quality, but only if interpreters had the opportunity to demonstrate their superior quality to clients (Felsö et al., 2007, p. xi), which is where the quality register comes in. As the report shows that average pay rates for interpreters in the public sector are approximately $20 \%$ below average rates in comparable professions (e.g. dieticians or speech therapists) (Felsö et al., 2007, p. xi), it is obvious that in view of the qualifications needed and the costs incurred for interpreting, there is hardly any room for reducing rates - quite the contrary.

A 2013 report on interpreter (and translator) tariff development commissioned by NGTV also concludes that the interpreter rates fixed in the Decision concerning Tariffs in Criminal Cases are below the average rates in economically comparable professions and only slightly higher than the average rates in healthcare interpreting (Baarsma \& Prins, 2013, p. 3). Compared to the tariffs in the private sector, the fixed rates are $30 \%$ lower (Baarsma \& Prins, 2013, p. 5).

\section{Conclusion}

This overview shows how the Dutch government has been actively involved in shaping the professional conditions for interpreters in the legal field, on the one hand, and how, on the other hand, it has gradually transferred the responsibility for the administration of PSI services and their financing to the users of these services. Apart from the contexts of legal and medical interpreting, other fields of public service interpreting are practically non-existent in the Netherlands in terms of quality control or legal provisions, as they are not mentioned in any kind of documentation or law.

As we have seen, the professionalization of legal interpreting in terms of quality is established in the Netherlands and appears to work reasonably well in this field, in spite of the practical difficulties mentioned above. These include the failure to verify effectively the afnameplicht, the legal obligation of certain institutions to work exclusively with certified interpreters. This policy is also in keeping with moves to implement EU Directive 2010/64/EU on the right to interpretation and translation in criminal proceedings.

However, a general development towards professionalization of public service interpreting as a whole is being undermined by the fact that there is no obligation to work with certified interpreters outside the field of legal interpreting, immigration and police services as well as a lack of quality control outside these domains. Although "field norms" were formulated for the use of interpreters in medical healthcare, these guidelines have never been binding and their implementation has become quite unrealistic since the withdrawal of government funding for healthcare interpreting in 2012.

In 2014, the guidelines were reformulated into "quality norms for the use of interpreters for non-native citizens in healthcare". In these "quality norms", as in the case of the field norms, the argument that the right to an interpreter in healthcare is enshrined in Dutch law is expressed, but (following the government's decisions regarding funding) the adapted guidelines no longer insist on the use of professional interpreters. Instead they recommend that healthcare providers follow a step-by-step plan in instances of possible 
language problems in order to find out whether the use of an interpreter is necessary in the first place, and in the second place whether this should be a professional or an informal interpreter (KNMG, 2014, p. 9). As with the field norms, the quality norms, which are still in use today, merely have an advisory function.

This overview of the developments in the government's role in the professionalization of public service interpreting in the Netherlands leads us to conclude that professionalization through certification applies only to legal interpreters, whereas any development towards the professionalization of interpreters outside the field of justice is seriously impeded by the lack of a legal framework for quality control and a lack of funding. The possibilities for interpreting training, the existence of a system of continuing education and the regulations concerning compensation all indicate a considerable level of professionalization in the Netherlands according to trait theory. However, as indications of professionalization have so far almost exclusively applied to legal interpreting, "public service interpreting" and "legal interpreting" have almost become perfect synonyms in the Netherlands. If other contexts of public service interpreting were to be included in the existing infrastructure of certification and training, then it can be said that the PSI sector in the Netherlands as a whole would benefit from an increased level of professionalism.

\section{References}

Baraldi, C., \& Gavioli, L. (2012). Coordinating participation in dialogue interpreting. Amsterdam: Benjamins.

Baarsma, B., \& Prins, J. (2013). Ontwikkeling tarieven tolken en vertalers in het publieke domein. [Development tariffs interpreters and translators in the public domain]. SEO, rapportnr. 2013-10.

Bermouna, S. (2013). De beëdigde tolk en vertaler binnen het justitieel domein. Een afstudeeronderzoek naar de juridische waarde van de akte van beëdiging van de beëdigde tolk en vertaler binnen het justitieel domein. [The sworn Interpreter and Translator in the domain of legal justice. A thesis on the legal value of the act of swearing in of the sworn interpreter and translator in the domain of justice]. Hogeschool van Amsterdam/Wbtv. Retrieved from http://www.rvr.org/nl/ news, 2013/10/2013-10-23-4-De-be-digd-vertaler.html?utm_source=Wbtv\&utm_ medium=email\&utm_campaign=E-nieuwsbrief + Tolken+en+Vertalers\%2C + nummer+9\%2C+23+oktober+2013

Bot, H. (2013). Taalbarrières in de zorg. Over tolkenbeleid en tolken met beleid. [Language barriers in health care. Interpreting policy and interpreting with care]. Assen: Koninklijke Van Gorcum.

Bureau beëdigde tolken en vertalers. [Bureau for Sworn interpreters and translators]. (n.d.). Beëdiging [Certification]. Retrieved from http://www.bureaubtv.nl/ Beediging.cfm

Bureau beëdigde tolken en vertalers. (n.d.). Inleiding Bureau beëdigde tolken en vertalers (Bureau btv). [Introduction Bureau for Sworn Interpreters and Translators (Bureau btv)]. Retrieved from http://www.bureaubtv.nl/ overbureaubtv.cfm?section=dummy

Bureau beëdigde tolken en vertalers. (2009). Gedragscode. [Code of conduct]. Retrieved from http://www.bureaubtv.nl/pdf/Wbtv\%20gedragscode.pdf

Bureau beëdigde tolken en vertalers. (2010). Landelijk profiel van eindcompetenties tolken Hbo-opleidingen Vertalen en Tolken Nederland. [National profile final competencies College of higher education Interpreters and Translators the Netherlands]. Retrieved from http://www.bureauwbtv.nl/pdf/Landelijk $\% 20$ profiel\%20van\%20eindcompetenties\%20tolken\%20hbo.pdf

Bureau beëdigde tolken en vertalers. (2012). Meerjarenbeleidsplan 2012-2015. [Longterm policy plan 2012-2015]. Retrieved from http://www.bureaubtv.nl/pdf/ Meerjarenbeleidsplan2012-2015def.pdf

Bureau beëdigde tolken en vertalers. (2013). Inschrijfvoorwaarden voor het Rbtv per 1 juli 2013. [Conditions for Inclusion in Rbtv Register from 1 July 2013]. Retrieved from http://www.bureaubtv.nl/tolk-vertaler/inschrijfvoorwaarden_2.cfm

Translation \& Interpreting Vol 7 No 3 (2015) 
Bureau beëdigde tolken en vertalers. (2015). Permanente Educatie. [Continuing education]. Retrieved from http://www.bureaubtv.nl/pe/

Carr, S., Roberts, R., Dufour, A., \& Steyn, D. (Eds.). (1997). The Critical Link: Interpreters in the Community. Papers form the 1st International Conference on Interpreting, Legal, Health and Social Service Settings. Amsterdam: John Benjamins. In C. Baraldi \& L. Gavioli (Eds.), (2012). Coordinating participation in dialogue interpreting. Amsterdam: Benjamins.

Corsellis, A. (2009). Public Service Interpreting: The First Steps. Basingstoke: Palgrave-McMillan. In Baraldi, Claudio \& Gavioli, Laura. (2012). Coordinating participation in dialogue interpreting. Amsterdam: Benjamins.

Doornbos, N. (2008). De regulering van de kwaliteit van tolken en vertalers: een rechtssociologische analyse. [The regulation of the quality of interpreters and translators: an analysis in terms of the sociology of law]. Nederlands Juristenblad, jrg. 83, 1219-1223. Den Haag: Kluwer.

Duijn, A. van, \& Reijen, M.K.G.J. van den. (2001). Rapport Werkgroep Gerechtstolken: De juiste tolk op de juiste plaats. Onderzoek naar tolken in de strafrechtspleging. [Report Working Group Legal Interpreters: the right interpreter at the right place: research on interpreters in criminal law practice]. Retrievedfrom http://www.home.zonnet.nl/taalrecht/JuisteTolk/GT\%202003\%20 rapport\%20met\%20bijlagen.pdf

Felsö, F., Baarsma, B., Gerritsen, M., \& Mulder, J. (2007). Tolken in het publieke domein. Over de vraag, aanbod en bemiddeling van tolken. [Interpreting in the public domain. Demand, supply and allocation of interpreters]. Amsterdam: Wetenschappelijk Onderzoek- en Documentatiecentrum (WODC). Retrieved from http://dare.uva.nl/document/2/67465

Hodson, R., \& Sullivan, T.A. (2001). Professions and professionals, in The social organization of work. Belmont CA: Thomson Higher Education. 287-314.

Houle, C.O. (1980). Continuing learning in the professions. San Fransisco: Jossey-Bass Publishers.

IGZ. (2006a). Kortschrift "Tolken in de gezondheidszorg”. [Digest "Interpreting in healthcare"]. Retrieved from http://www.igz.nl/zoeken/document. aspx?doc0 Kortschrift+Tolken+in+de+gezondheidszorg\&docid=1476

IGZ. (2006b). Veldnormen voor de inzet van tolken in de gezondheidszorg. [Field Norms for the use of interpreters in health care]. Retrieved from http://www.crisiskaartggz.nl/crisiskaart/download/tolkdiensten/veldnormen_inze t_tolken_in_gezondheidszorg_definitief_tcm19-95004.pdf

Kleij, S. van der. (2015). Interaction in Dutch asylum interviews. A corpus study of interpreter-mediated discourse. Utrecht: Lot.

KNMG (2011). KNMG-standpunt Tolken in de Zorg. [Opinion of the Dutch Society for the Advancement of Medicine on Interpreting in Healthcare]. Retrieved from http://knmg.artsennet.nl/Publicaties/KNMGpublicatie/KNMGstandpunt-Tolkenin-de-zorg-2011.htm.

KNMG et al. (2014). Kwaliteitsnorm tolkgebruik bij anderstaligen in de zorg. [Quality Norms for the use of interpreters for non-native citizens in healthcare]. Retrieved from http://knmg.artsennet.nl/Publicaties/KNMGpublicatie/142783/ kwaliteitsnorm-tolkgebruik-bij-anderstaligen-in-de-zorg-2014.htm

Kwz (Kwaliteitswet Zorginstellingen) [Quality of Healthcare Institutions Act] (19-011996). Retrieved from http://wetten.overheid.n1/BWBR0007850/ geldigheidsdatum_09-03-2015.

Larson, M.S. (1977). The rise of professionalism: a sociological analysis. Berkeley: University of California Press.

Mikado (2012). Wij zijn sprakeloos. [We are speechless]. Retrieved from http://www. wijzijnsprakeloos.nl/

Ministeries van Justitie en voor Vreemdelingenzaken en Integratie [Ministries of Justice and of Immigration and Integration] (2004). Brief aan de Voorzitter van de Tweede Kamer der Staten-Generaal. Interdepartementaal Beleidsonderzoek: Tolken en Vertalers: aanbevelingen voor een kwalitatief goed en financieel beheersbaar stelsel [Letter to the president of the Dutch Lower Chamber. Interdepartmental Policy Research: Interpreters and Translators: recommendations for a qualitative and financially manageable system] Retrieved from http://parlis.nl/pdf/ kamerstukken/KST75097.pdf

Ministerie van Veiligheid en Justitie, Immigratie- en Naturalisatiedienst, Publicatienummer 1106. [Ministry of Safety and Justice, Immigration and 
Naturalisation Service] (2014). Gedragscode tolken. [Code of conduct]. Retrieved from https://www.ind.nl/Documents/1106.pdf

Ministerie van Volksgezondheid, Welzijn en Sport [Ministry of Public Health, Wellbeing and Sports]. (2013). Kamerbrief over de inzet van tolken. [Parliamentary publication on the use of interpreters]. Retrieved from http://www.rijksoverheid.nl/documenten-en-publicaties/kamerstukken/ 2013/05 /28/kamerbrief-over-inzet-tolken.html

NGTV (Nederlands Genootschap voor Tolken en Vertalers) [the Netherlands Association of Interpreters and Translators]. (2015). Tolken werken niet voor opgelegde dumptarieven. [Interpreters do not work at imposed inferior rates]. Retrieved from https://www.ngtv.nl/nieuws/algemeen-nieuws/tolken-werkenniet-voor-opgelegde-dumptarieven

Osenbruggen, A. van, et al. (2009). Kosten- en batenanalyse van tolkdiensten. Eindrapport. [Cost benefit analysis of interpreting services. Final report]. Amsterdam: Regioplan Beleidsonderzoek. Retrieved from http://www. rijksoverheid.nl/documenten-en-publicaties/rapporten/2013/03/21/ kosten-enbatenanalyse-van-tolkdiensten-regioplan.html.

Pemberton, A. (2001). Participeren of niet? Het kwaliteitstraject voor Tolken en Vertalers [To participate or not to participate? The quality trajectory for Interpreters and Translators]. Leiden: Research voor Beleid.

Pym, A., Grin, F., Sfreddo, C., \& Chan, A. L. J.(2012). The status of the translation profession in the European Union. Final Report. Luxembourg: Publications Office of the European Union. Retrieved from http://ec.europa.eu/dgs/translation/ publications/studies/translation_profession_en.pdf

Raad voor Rechtsbijstand. [Legal Aid Board]. (2015). Jaarverslag 2014. [Annual report 2014]. Retrieved from http://rvr.turnpages.nl/DS/public/ slot00002/pdf/ compleet. pdf

Skipr Redactie (2012). Ziekenhuizen betalen tolken zelf. [Hospitals pay interpreters themselves]. Retrieved from http://www.skipr.nl/actueel/id9852-ziekenhuizenbetalen-tolken-zelf.html.

Staatsblad van het Koninkrijk der Nederlanden. [Kingdom of the Netherlands Bulletin]. (16 August 2003). Besluit tarieven in strafzaken. [Decision on tariffs in criminal cases].

Staatscourant. [Government Gazette]. (2011). Besluit Uitwijklijst Wbtv. [Alternative Register Decision Wbtv-law]. Retrieved from http://www.bureaubtv.nl/pdf/ besluit_uitwijklijst_m_i_v_31_12_2011.pdf

Staatscourant. (2012a). Besluit specialisatie. [Specialization Decision]. Retrieved from http://www.bureaubtv.n1/pdf/Besluit_specialisatie.pdf

Staatscourant. (2012b). Besluit aanwijzing specialisatie. [Indication Specialization Decision]. Retrieved from http://www.bureaubtv.nl/pdf/Besluit_ aanwijzen_ specialisatie.pdf

Staatcourant. (26 June 2013). Besluit Uitwijklijst Wbtv. [Alternative Register Decision Wbtv]. Retrieved from http://www.bureauwbtv.nl/pdf/stcrt-2013-17541 \%20 Besluit\%20Uitwijklijst.pdf

Staatscourant (2 February 2015a). Besluit Permanente Educatie Wbtv. [Continuing Education Decision]. Retrieved from http://www.bureaubtv.nl/pdf/ Besluit\% 20 PE\%20Wbtv\%20stcrt\%20030215.pdf

Staatscourant. (4 February 2015b). Regeling uitbreiding afnameplicht Wbtv [Extension Regulation afnameplicht]. Retrieved from https://zoek.officielebekendmakingen. $\mathrm{nl} / \mathrm{stcrt}-2015-4089 . \mathrm{html}$

Stejskal, J. (2003). Lessons learned. The ATA Chronicle, 32(8), 15-18 (August 2003). Retrieved from http://www.cetra.com/uploads/Files/2003-08.pdf.

Visser, J. (2012). Ziekenhuizen betalen tolken uit eigen zak. [Hospitals pay interpreters from their own pockets]. Retrieved from http://medischcontact.artsennet.nl/ actueel/nieuwsbericht/109161/ziekenhuizen-betalen-tolken-uit-eigen-zak.htm.

Waz (Wet Afbreking Zwangerschap) [Abortion Act]. (01-05-1981). Retrieved from http://wetten.overheid.nl/BWBR0003396/geldigheidsdatum_09-03-2015

Wbtv (Wet Beëdigde Tolken en Vertalers) [Sworn Interpreters and Translators Act]. (11 October 2007). Retrieved from http://wetten.overheid.nl/BWBR0022704/ geldigheidsdatum_10-03-2015\#Opschrift

Wbig (Wet op de beroepen in de individuele gezondheidszorg) [Professions in Individual Healthcare Act]. (11-11-1993). Retrieved from http://wetten.overheid. nl/BWBR0006251/volledig/geldigheidsdatum_09-03-2015 
Wgbo (Wet op de Geneeskundige Behandelingsovereenkomst) [Medical Treatment Agreement Act]. (20-09-2012). Retrieved from http://wetten.overheid.nl/ BWBR0005290/volledig/geldigheidsdatum_20092012\#Boek7_Titel7_Afdeling5

Wkgz (Wet klachtrecht cliënten zorgsector). [Clients' Right to Complaints Act]. (2905-1992). Retrieved from http://wetten.overheid.nl/BWBR0007414/ geldigheidsdatum_09-03-2015

Wilensky, H.L. (1964). The professionalization of everyone? American Journal of Sociology $70(2)$.

Witter-Merithew, A., \& Johnson, L. (2004). "Market disorder within the field of sign language interpreting: professionalization implications". Journal of Interpretation, 19-55. 